\title{
Integrated Reporting Based on Maqasid Al-Shariah: A Proposed Framework for Islamic Non-Profit Organizations
}

\author{
Nathasa Mazna Ramli ${ }^{1}$, Nur Solehah Aqilah Md Ali ${ }^{2}$, Nurul Aini Muhammed ${ }^{3}$ \\ ${ }^{1}$ Faculty of Economics and Muamalat, Universiti Sains Islam Malaysia (USIM), Malaysia \\ $\triangle$ (e-mail)nathasa@usim.edu.my \\ ${ }^{2}$ Faculty of Economics and Muamalat, Universiti Sains Islam Malaysia (USIM), Malaysia \\ $\triangle$ (e-mail) solehahaqilah720@raudah.usim.edu.my \\ ${ }^{3}$ Faculty of Economics and Muamalat, Universiti Sains Islam Malaysia (USIM), Malaysia \\ $\triangle$ (e-mail) nurulaini@usim.edu.my
}

\begin{abstract}
This research focuses on Islamic non-profit sector which rely on sources from the public. The emergence of this sector can be strengthened by fulfilling the needs of stakeholders for efficient reporting mechanism. Assessing the reporting of the sector would be notable to ensure that it obtains its objectives. Efficient reporting practices should highlight the non-profit perspectives and religious aspects. This research aims to identify the principles of Integrated Reporting (IR) that are suitable for Islamic non-profit organizations that draw its root from zakat, waqf and sadaqah (charity). This research focuses on formulating an IR framework whichis in line with Maqasid al-Shariah concept. IR is a new reporting concept that is holistic, strategic and relevant which represents a more meaningful reporting. This paper theoretically explores and proposes the IR for Islamic non-profit organization in the way to manifest their accountability towards stakeholders. The propose IR framework is expected to make contribution in several aspects. For donors, the IR is expected to be source for decision making. The proposed framework of IR will also guide the board and management in communicating the accountability of Islamic non-profit organizations. The developed IR framework can be an effective communication mechanism that can safeguard missions and visions of the organizations.
\end{abstract}

Keywords: integrated reporting, maqasid al-shariah, non-profit organizations, Islamic finance, Islamic social finance

\section{Introduction}

It is estimated that Muslims' contribution in term of Islamic social funds are within USD250 billions to USD1 trillion per year (Alterman et al, 2005). Obaidullah and Shirazi (2015) supported the huge amount of Islamic social funds in the world by stating that there are in excess about USD600 billions of zakat from Organization of Islamic Cooperation (OIC) members countries. The Islamic social funds indeed can be annually distributable for the economics development of Muslim world, including for humanitarian action. In the World Islamic Economic Forum 2015, it was highlighted that the world is facing humanitarian crisis and stressed the needs for humanitarian financing (WIEF, 2015). The utilization of Islamic social finance, namely zakat, sukuk, waqf or sadaqah, has been proposed to have the potential to reduce the huge financial gap that exists in humanitarian financing. Even though the amount of Islamic social funds is large, humanitarian funding is still shortfall. Looking at the potential of Islamic social finance, organizations that handle these financing tools need to communicate their accountability so that the collected funds can be increased. Generally, issues of humanitarian are addresses by non-profit organizations (NPOs) in most developing countries. There are certain NPOs which are purely foreign in nature, however in third world countries some NPOs are local but funded from abroad (Jamil, 1998). 
Sadly, Islamic NPOs, who mostly handle the Islamic social finance for philanthropic and humanitarian aid in third world Muslim countries, have been accused of being involved in terrorism financing (Othman and Ameer, 2014). The accusation raise question on the accountability of the organizations and also increase the organizations' risk. As a consequence, donors might not channel their donations and stakeholders would not have trust on the organizations. Islamic NPOs are suspected as conduits for terrorist financing through mobilization of financial resources and religious traditions of zakat and sadaqah (Hardister, 2003; McCullohand Pickering, 2005; Sproat, 2005).Looking at the potential of Islamic social finance and the risk related the organizations, Islamic NPOs need to be transparent and communicate their accountability. Effective and efficient communicate accountability can overcome the accusation and thus, attract donors. In a long run, Islamic NPOs could become sustainable and meet their missions.

Published reports, such as annual reports are widely regarded as an important means of discharging accountability in the corporate sector. These reports may be one of the means by which Islamic NPOs can improve stakeholders' perceptions of their accountability. Empirical evidence shows that high level of transparency and disclosure can increase confidence among decision-makers such as donors. Buchheit and Parsons (2006) and Trussel and Parsons (2008) have found positive relationships between the extent of disclosure and the amount of future donations received. Atan et al. (2012) concluded that the financial information provided by Malaysian charities can influence a potential donor's decision to donate. They proposed that the management of NPO need to improve their financial disclosure information in order to attract more support from donors. It can be concluded that the donor's decision to donate depends on the level of transparency of the charity organizations.

However, published reports should not only contain financial information, but also non-financial information. Stakeholders of Islamic NPOs such as donors, beneficiaries and the public requires new information and measurement, particularly issues on transparency, and performance and value measurement. These leads to proposition for all type of organizations to adopt an IR, which covers more than financial elements. However, the nature of corporations and NPOs are different from one and another. Among the differences of the organizations are their purpose, ownership and source of funds. Islamic NPOs are characterized by their dependence on public donation, government grant funding and members fees. In return, Islamic NPOs need to provide information to their stakeholders to report their activities, financial and other related information. Failure to convey adequate information may be cause negative perception toward the organization's effectiveness in managing their fund. On top of that, Maqasid Al-Shariah, or the objectives of Sharia should be the underlying principles for the Islamic NPOs in reporting

IR is a new approach to reporting that may represent the next development of accounting (Adam and Simnett, 2014). This paper proposed an IR framework for Islamic NPOs based on Maqasid AlShariah. In the next section, this study discussed the Islamic NPOs. The concept of accountability, which is the basis of the study, is discussed in the next section. Then, the study discussed IR which includes the definition, benefits and identification of IR principles. The need of Islamic framework that is suitable for Islamic NPOs are also discussed in that section. This paper also highlighted the concept of Maqasid Al-Shariah and the importance of IR of Islamic NPOs which adhere to Maqasid alShariah concept. Based on the discussion of literature, this research developed a Maqasid Al-Shariahbased IR framework for Islamic non-profit organizations. The proposed IR framework is expected to make contribution in several aspects. For donors, the IR is expected to be source for decision making, which may be different from conventional NPOs. The proposed framework may also guide the board and management in communicating the accountability of Islamic NPOs. The developed IR framework can be an effective communication mechanism that can safeguard missions and visions of the Islamic NPOs. 


\section{Islamic Non-profit Organizations}

Generally, there are three economic sectors namely public sector, private sector and non-profit sector. Public sector contains of governments and all publicly controlled or publicly funded agencies, enterprises and other entities that deliver public programs, goods or services (IIA, 2011). While the private sector consists of private and all individuals or groups of companies, enterprises, organizations and other entities that operates with maximizing profit as main objective (UNDP, 2012). Finally, non-profit sector consists of civic and all socials organizations, institutions, agencies and other entities apart of public and private sectors (Frumkin and Keating, 2002). Berger (2003) claimed that there are millions of NPO in existence that define themselves as "religious", "spiritual" or "faithbased" NPOs, and this number keeps increasing.

NPO is established to fulfil several functions that may overlaps with each other. These functions are educational, religious, charitable, scientific, literary, testing for public safety. An NPO can be defined as an organization that has "predominantly non-business characteristics that heavily influence the operations of the organization" (FASB, 1980). Othman et al. (2012) clearly stated that NPOs do not have shareholders with possibly unclear goals, so that their interests vary. Instead of generating profit, NPOs aim is generally to create social value. Thus, accountability is an important element for donors and volunteers of NPOs to evaluate whether or not to donate or volunteer their services to the organizations. Islamic NPOs are closely related to charity organizations that focus on philanthropic and humanitarian activities.

According to Kuran (2001), the judiciary form of Islamic NPOs such as ijtima' institutions (zakat, waqf and sadaqah based institutions) are established during $2^{\text {nd }}$ and $3^{\text {rd }}$ of Islamic century. However, it is believed that those institutions are established earlier during Prophet Muhammad SAW era with the evidence of establishment of Baitul-mal, the one who manage the national financial treasure including zakat, waqf and sadaqah. These institutions continue and expand in the glory era of Khulafa' Ar-Rasyidin. Moreover, Islamic NPOs are not only limited to support religion works, but it also contributes to other activities such as education projects, community engagements and humanitarian reliefs (Alam, 2010).

Similar like other NPOs, Islamic NPOs also received donations from public to conducts activities. However, these donations or known as Islamic social finance can be classified into several types i.e. zakat, waqf, sadaqah and others. Each of types of Islamic social finance are different from one another based on its purposes and status (ISRA, 2011; and Sheila et al., 2012).

\section{Integrated Reporting (IR) and the Need of Islamic Framework}

Rossouw (2011) mentioned that IR is a disclosure of forwards looking information, assurance on the quality of this type of information, annual presentation, positive aspect and challenges, holistic and integrated view on financial and sustainability elements. In addition, IR also covers performance, assurance on material sustainability or non-financial issues. IR is a management and communication tool for understanding and measuring how organizations create value now and in the future. Therefore, it can be concluded that IR is a concept that has been created to better articulate the broader range of measures that contribute to long-term value and the role organization plays in society.

Specifically, IR is defined as the linkages between an organization's strategy, governance and financial performance and the social, environmental and economic context within which it operates. By reinforcing these connections, IR can help business to take more sustainable decisions and enable investors and other stakeholders to understand how an organization is really performing. (International Integrated Reporting Committee, 2011)

Several studies have highlighted the benefits of IR. Robert et al. (2011) stated that IR provides benefit to the management as it gives better understanding and clearly articulated statements about the relationship between financial and non-financial performance. IR also provides better risk 
management and better engagement with current and prospective employees and other stakeholders. Owen (2013) summarized that IR gives review of the organization, its governance structure, its core activities and how it creates and adds value for stakeholders. Robert and Shachzman (2011) viewed that IR assists management in internal resource allocation decision, provide greater engagement with stakeholders and lower reputational risk. Prior studies mostly discuss IR's benefit from For ProfitOrganizations' perspectives. However, IR also suitable to be adopted by NPOs.

Adams and Simnett (2011) stressed that IR presents an appropriate framework for NPOs as it could provide fertile ground for improving and reducing the burden of NPO reporting. NPOs can benefit from compliance-based approach to more flexible and organization-centric reporting. IR could capture the diverse goals and activities of NPOs, thus provide more meaningful reporting. In addition, IR could capture non-financial measures which are the core of NPOs' operation. Examples of the non-financial elements are volunteers, gifts-in-kind and other non-monetary and non-physical resources that contribute to value creation of NPOs. NPOs are already integrated in their activities, therefore the next step is how to govern the 'integrated' thinking in their reports.

NPOs characteristic have relationship with the excellence of IR. The type of industry, size of an entity, the profitability and composition of the board of directors, all have an effect on the quality of the IR (Buitendag. N, 2017). Dissatisfied with the conventional economics and its limitations to address economic problems of today, there is need to have a more realistic generic theory of economics capable of explaining economic behavior of any society given the socioeconomic and institutional parameters of that society (Khan, 2013). Therefore, there is a need of Islamic framework of IR, which catered specifically for Islamic NPOs. The unique characteristics and objectives of Islamic NPOs may requires a specific reporting practices.

\section{Accountability}

Reporting and disclosure is one of mechanism for organization to discharge accountability. Accountability can be defined as the state of being accountable or liable. Accountability can also be referred as the quality or state of being accountable especially in an obligation or willingness to accept responsibility or to account for one's action. Gray and Jenkins (1993) defined accountability as "the duty to provide an account (by no means necessarily financial) or reckoning of those action for which one is held responsible".

Accountability in context of non-profit organization is how an organization portrays transparency or being accountable in providing information to satisfy the information needs of their stakeholders (Hydman, 1990). Ramli et al. (2016) believe that accountability is a benchmark of being accountable, in term of a sense of willingness to accept responsibility to an action. Accountability is an obligation to government by prepared report and emphasize proven standard by practice transparency to public in all aspect. Stakeholders have a reasonable right to be provided with information that meets their needs. However, due to the fact that they normally have no powers of interrogation, they must rely on annual reports to meet their needs (Hydman, 1990). Saunah (2013) believe that accountability can be shown into clear expectations for non-profit activity, for instance, filing annual report and any activities that giving back to the society.

Candler and Dumont (2010), found that accountability to whom and accountability to what are related. Accountability to who is basically relation between all the key stakeholders included employees, investor, communities, supplies, trade association, political group, customer and government. Candler and Dumont (2010) found also there are 3 types of accountability, which are: 1) inputs (financial resources, volunteer resources, reputational capital); 2) outputs (good and services, social capital, policy impact; and 3) procedural (law, formal mission, ethics legitimacy). For instance, accountable to funder, NPO has high accountability in ensuring that the resources distributed wisely. As for government, NPO accountable to follow the law while for communities, NPO need to be accountable to the public trust given. 
Lewis (2006) stressed that the primary objective of an accounting is to aid accountability. Those in charge or economic resources must give their stewardship, irrespective of whether the transaction and resources in question those are in government organization or private sector entity. Yaacob, Petra and Nahar (2012) stated that Islamic accounting concepts argued that accounting and reporting in the Sharia is more than just numbers and some qualitative aspects. In fact, the spirit of 'ibadah' and the accountant should report any information as long as it is true. Furthermore, they should disclose other information (non-financial included) whether mandated or not by the International Accounting Standards (IASs) or International Financial Reporting Standards (IFRS).

\section{Maqashid Al-Shariah}

Ibn Asyur (1978) defined Maqasid as the meaning and wisdom observed by the Sharia in every state of affairs or substantially. The observation is not limited to certain types of Islamic law. Every Muslim soul's will work hard to achieve it with various efforts and withstand all the hardships in order to execute Allah command. Maqasid Shariah is acknowledged as high-level rank direction in guiding the Sharia judgment. Adopting Maqasid Shariah in guiding human activities and justifying $h u k m$ is important especially when there is no judgment has been issued on the events that do not exist in the past. Figure 1 illustrates the relationship between the two concepts (Abdullah, 2006). Obeying the command to protect these five elements of Maqasid Syariah is very important to ensure that all needs, wants, and life aspirations can be fulfilled in order to attain happiness and prosperity in this world and hereafter.

Rahman (2014) mentioned the purpose of Allah outlines the Sharia is to preserve the maslahah of human being. Al Shatibi views maslahah as being concerned with the subsistence of human life, the completion of man's livelihood and the acquisition of what his emotional and intellectual qualities require of him in absolute sense. Al-Ghazali stated the purpose of maslahah is to bring benefits and resist harm and divided Maqasid al-Shariah into five important elements, which are protection of human self (nafs), faith (ad-din), human intellect, human generation and resources/wealth. These five elements are posited under the necessities (daruriyyat).

\section{Protection of faith (ad-din)}

Rahman (2014) stated the fundamental aspect of Maqasid Shariah is religion. Religion of an individual would govern the acts of human being in many aspects: economic, political and social, which clearly stated that individuals are prohibited from performs in any conducts against the Sharia but instead should seek the blessing of Allah. Therefore, it is in human nature to have religion as guidance. In this context, Islam is the religion that can fulfil this human natural need which requires a life guidance to save them from destruction. Rahman et al. (2017) believed that safeguarding the religion catalyst Muslim in purification of their wealth and gaining Sharia compliance source of income.

\section{Protection of human self (nafs)}

The scholars have defined the protection of life with various definitions. Ibn Ashur (2006) defined protection of life as safeguarding it from anything that can cause damage, whether involving life of an individual or mankind as a whole. The protection of life can be seen from the aspect of fulfilling the basic needs of human itself, which are the physical, spiritual, moral, and social needs, as well as avoiding anything life-threatening (Ruzita et al., 2013). Therefore, it is an obligation of mankind to completely protect life given by Allah SWT Mankind have to avoid from getting involved with dangerous or careless acts, whether directly or indirectly, that can cause danger to their own life or others.

\section{Protection of human intellect}

According to Ibn Asyur (2006), protecting mind means protecting it from anything that can lead human to destruction. He explained that an unsound mind will cause a person to behave 
irrationally or insanely, and wrongly. This portrays Islam as emphasizing the followers to protect and preserve the mind from anything that can cause corrupt and damage. The mind is the most important function in human life to ensure a better quality of life. The mind is a blessing given by Allah s.w.t to human so that human can always think, understand and appreciate His creations, whether in the heaven or on the earth.

\section{Protection of human generation}

The concept of protecting lineage or dignity encompasses the protection, preservation and support of lineage (Kasule, 2004). Few authors stated that protecting lineage starts from the beginning of marriage (Kasule, 2004; Syarifuddin, 2004) such as the responsibility of husband, wife, parents and children. The responsibilities includeswhether in the form of material, spiritual, or proper education. This is because the responsibility of each individual is important in preparing the future generation to face the challenges of life (Chapra, 2007). The dimensions to measure lineage are relationship with family, relationship with neighbors, law enforcements (Mahadzirah et al., 2014).

\section{Protection of resources/wealth}

According to Ibn Manzur (1993), property or asset means anything owned by a person among everything. Wealth is a part of adornment of life that enables human to enjoy a better life, but not excessively. Rahmanet. al (2017) believed that safeguarding the wealth by quitable distribution of income and wealth. Maqashid Shariah in this context is a perfect guideline covering muamalat.The protection of wealth thus can be summarized as related to accumulating and distributing wealth in the way that is guided by Shariah.

The scope for this study, therefore is to analyze the Sharia guidelines for Islamic finance for general business entities and non-profit organizations in particular.

Islamic law, or Sharia, regulates all aspects of life. Every act of the believers must conform to Islamic law and observe ethical standards that are derived from Islamic principles. These ethical principles define what is true and fair, the nature of corporate responsibilities, the priorities to society, along with some specific governance standard. This research proposed the IR with compliance to Maqasid al Shariah.

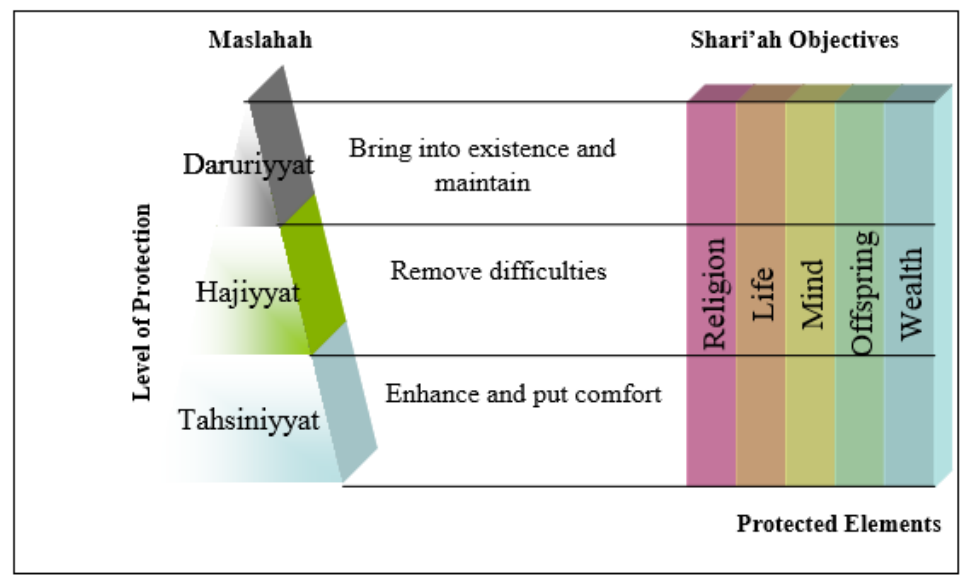

Source: Abdullah, 2006

Figure 1 The Relationship between the maslahah concept and doctrine of Sharia objectives

Hasan and Asutay (2009) stated stakeholders maslahah in wealth management classified into the state as the regulator, shareholders, managers, employees, communities and environment (refer to Figure 2). 


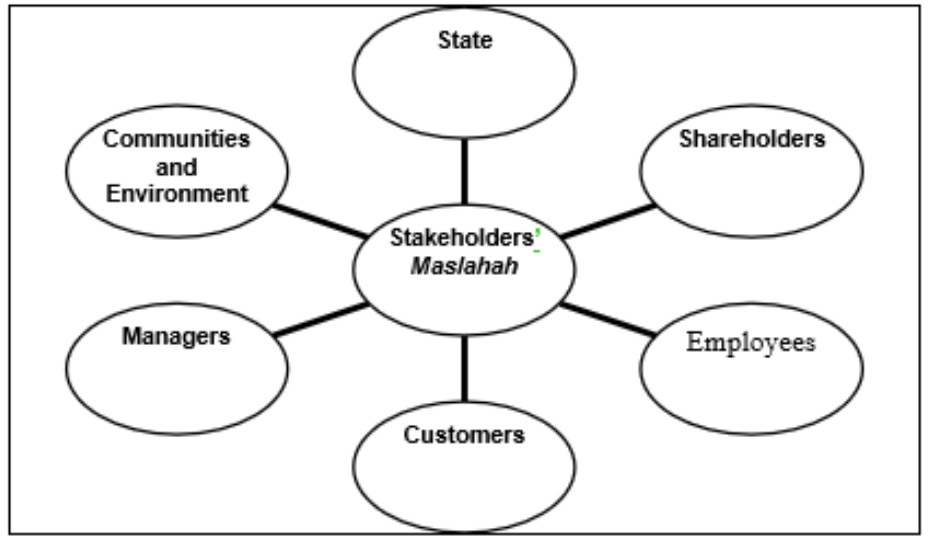

Source: Hasan and Asutay (2009)

Figure 2 Stakeholders' maslahah in wealth management

Shareholders' maslahah include wealth maximization, satisfactory earnings per share, excellent continuous growth, high integrity, efficiently and effectively managed company. Maslahah in business is how to maximize wealth. Same goes for nonprofit organizations, maslahah is also subject to stakeholder intention toward reporting disclosure. Non-profit organizations owe their stakeholders a robust reporting disclosure.

\section{Developing an IR Framework Based on Maqasid Al-Shariah}

This study is a conceptual attempt to discuss the topic. Hence, it will be a qualitative in nature. This study applied a content analysis method through deep and intense readings of the previous texts and literatures related to the topics. This research applied both the inductive and deductive methods to thoroughly examine and analyze the relevant literatures and develop the relationship between maslahah and Sharia objectives with the mainstream framework of IR. The proposed analytical framework of this study is illustrated in Figure 3.

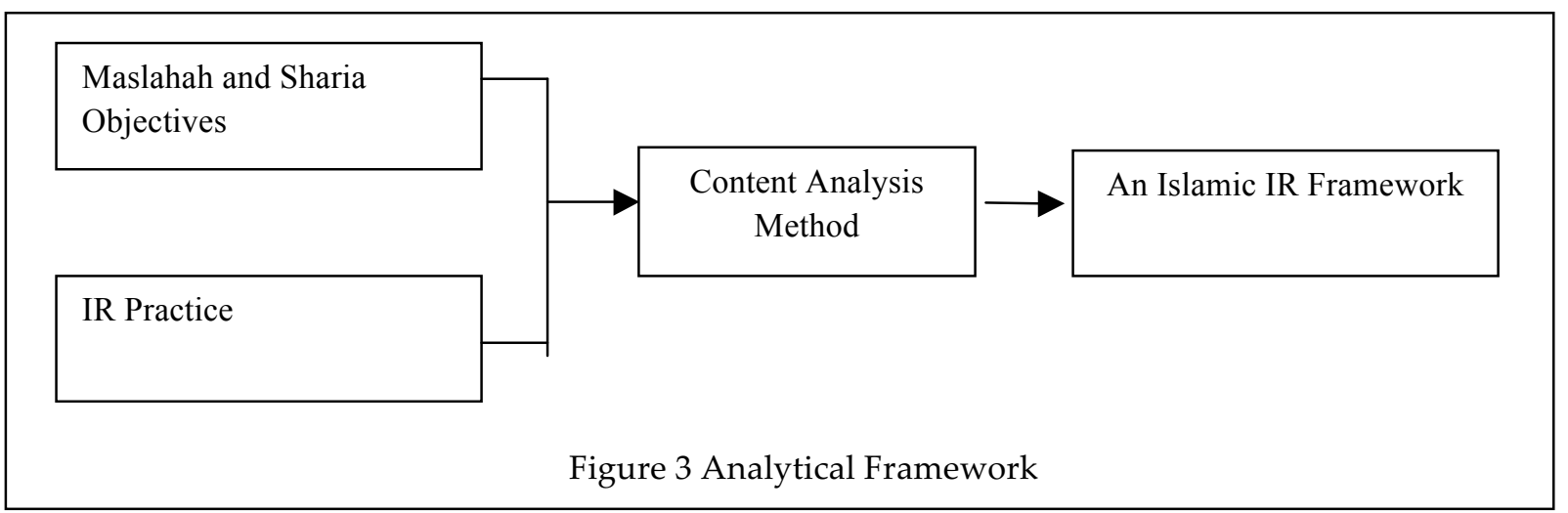

Based on previous discussion, this paper proposed an IR framework for Islamic NPOs, which is shown in Figure 4. Based on the figure, the five pillars of Maqasid-Al Shariah will be the ultimate objective of Islamic NPOs in pursuing IR. As an Islamic institution, Islamic NPOs should put up front the objective of Sharia in communicating its accountability. The eight dimensions of IR should not be set aside by the Islamic NPOs, as these dimensions covers the necessary reporting that could meet the demands of stakeholders. Stakeholders, as the heart of Islamic NPOs need to be taken care of. An effective and efficient reporting framework could become the tool for discharging accountability. The maslahah of stakeholders needs to be taken into consideration when reporting the activities, governance and performance of Islamic NPOs. 


\section{Maqasid al Syari'ah Maslahah}

\begin{tabular}{|l|l|c|}
\hline \multicolumn{2}{|c|}{ Five Protected Elements } & Levels of Protection \\
\hline Religion (Deen) & Faith & \multirow{2}{*}{ Essential } \\
\hline \multirow{3}{*}{ Worldly (Duniawi) } & Human-self & \multirow{2}{*}{ Complementary } \\
\cline { 2 - 2 } & Human Intellect & Embellishment \\
\cline { 2 - 2 } & Human Generation & \\
\cline { 2 - 2 } & Wealth & \\
\hline
\end{tabular}

\section{IR Content Elements}

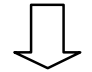

\begin{tabular}{|l|l|l|l|l|l|l|l}
\hline $\begin{array}{l}\text { Organizational } \\
\text { overview }\end{array}$ & Governance & $\begin{array}{l}\text { Business } \\
\text { Model }\end{array}$ & $\begin{array}{l}\text { Risks and } \\
\text { Opportunities }\end{array}$ & Strategy & Performance & Outlook & $\begin{array}{l}\text { Basis } \\
\text { presentation }\end{array}$ \\
\hline
\end{tabular}

\section{5 \\ Stakeholders' Maslahah in Reporting Disclosure Prioritization based on Sharia Value}

Figure 4 IR Framework based on Maqasid Al-Shariah

\section{Conclusions}

This study seeks to incorporate IR based on Maqasid Al-Shariah, which is needed since existing western understanding of IR used by organizations might contradict with Islamic sharia. Islamic NPOs requires reporting mechanism that become a reflection of their commitment to certain Sharia goals that ensure the welfare of stakeholder groups. This paper provided initial stage in developing IR based on Maqasid Al-Shariah, where the proposed framework linked Maqasid Al-Shariah with eight dimensions of IR. The framework prioritized the stakeholders of Islamic NPOs, where prioritization is based on Sharia Value.

This study has laid the groundwork for several strands of future research. Since this study was based on review of literature, future research could focus on stakeholders' perception relating to IR, particularly what are information needs of the stakeholders. The input from the stakeholders can be integrated with the developed framework. In addition, the perception and understanding of the board and management of NPOs also needs to consider in relation to IR, Maqasid Al-Shariah, accountability and stakeholders. As a conclusion, analysis from multiple perspectives is needed to explore the IR Framework based on Maqasid Shariah, which focuses on Islamic NPOs. The wide stakeholders of Islamic NPOs, internal and external, have to be taken into consideration in developing a robust IR framework based on Maqasid Al-Shariah. 


\section{Acknowledgement}

We would like to express our gratitude to Ministry of Higher Education of Malaysia for the grant provided to execute the project entitled Formulating IR Framework Islamic Social Finance Institutions (USIM/FRGS/FEM/32/50416).

\section{References}

Abdullah J. (2006). The Significances of Maslahah Concept and Doctrine of Maqasid (Objectives) AlShariah In Project Evaluation. The Journal of Muamalat and Islamic Finance Research, 3, 56-72.

Adams, S. \& Simnett, R. (2011). Integrated reporting: an opportunity for Australia's not-for-profit sector. Australian Accounting Review, 21(3), 292-301.

Atan, R., S.\&YB Wah. (2012). Quality information by charity organizations and its relationship with donations. Recent Advances In Business Administration, 118-123.

Berger, A. (2014). Media and Communication Research Methods. An Introduction to Qualitative and Quantitative Approaches. 3rd ed. Thousand Oaks: SAGE Publications, Inc.

Buitendag, N. (2017). Firm characteristics and excellence in IR. South African Journal of Economic and Management Sciences, 629-637.

Busco, C., Frigo, M., Paolo Quattrone \& Angelo Riccaboni, (2013). Redefining corporate accountability through - IR: What happens when values and value creation meet? Strategic Finance, 33-41.

Candler, G. \& Dumont, G. (2010). A non-profit accountability framework. Canadian Public Administration, 539(2), 259-279.

Chapra, M. U. (2007). The Islamic Vision of Development in the Light of Maqāsid AlSharī’ah. Retrieved from http://www.irti.org/iri/go/km/docs/documents/IDBDevelopments/Internet/ English/IRTI/CM/downloads/Distance_Learning_Files/The Islamic Vision of Development 7. pdf.

Financial Accounting Standards Board (FASB). (December, 1980). Concepts Statement No. 4.

Frumkin, P., \& Keating, E. (2002). The risks and rewards of nonprofit revenue concentration. Faculty Research Working Paper Series. Hauser Center for Nonprofit Organizations.

Gray, A., \& Bill J. (1993). Codes of accountability in the new public sector. Accounting, Auditing and Accountanbility, 3, 52-67.

Hardister, A. (2003), Can we buy peace of earth? The price of freezing terrorist assets in a postSeptember 11 world, North Carolina. Journal of International Law and Commercial Regulation, 28, 605-661.

Hasan, Z., \& Asutay, M. (2009). Maslahah in stakeholder management for Islamic financial institutions. Islamic Figh Academy of OIC, 1- 2.

Ibn A. (2006). Treatise on Maqasid al-Shariah. The International Institute of Islamic Thought, London.

Imam S. (2004). Maqasid al-shari'ah dan kepentingannya di dalam ijtihad, (Unpublished master's thesis). Universiti Kebangsaan Malaysia, Kuala Lumpur, Malaysia.

Jamil, I. (1998). Transactional friction between NGOs and public agencies in Bangladesh: Culture or dependency? Contemporary South Asia, 7(1), 43-69.

Kasule, O., H. (2004). Preservation of progeny: A medical perspective (Maqasidhifdh al nasl: Al manduur al tibbi). Paper presented at an International Seminar on Genealogy and Preservation of the Progeny-Islamic Perspective, Kuala Lumpur.

Khan, M., F. (2013). Theorizing Islamic Economics: Search for a Framework for Islamic Economic Analysis. JKAU: Islamic Econ., 26(1), 209-242.

Kuran, T. (2001). The provision of public goods under Islamic law: Origin, impacts and limitations of the waqf system. Law and Society Review, 35, 841-387.

Lewis, M., K. (2006). Accountability and Islam. Doctoral Dissertation. University of South Australia.

Mahadzirah, M., Azman M., A., Nasir, M., Wan, M., Y., Wan, C., Norhilmi, M., \&Fazida, K. (2014). Kualiti Hidup Pendekatan Maqasid Syariah. Kuala Terengganu, Terengganu: Universiti Sultan Zainal Abidin Publisher. 
Othman, R, \& Ameer, R. (2014) Institutionalization of risk management framework in Islamic NGOs for suppressing terrorism financing: Exploratory research, Journal of Money Laundering Control, 17(1), 96-109, doi: org/10.1108/JMLC-02-2013-0006.

Obaidullah, \& Shirazi, N. S. (2015). Islamic Social Finance Report 1436H. Islamic Research and Training Institute (IRTI). Jeddah.

Radiah O., Norli A., Normah O., \& Rashidah A., R. (2012). Practical challenges in managing nonprofit organizations (NPO): Tales from two neighboring countries. International Bulletin of Business Administration, 13(13), 6-23.

Rahman, A., R., A., \& Goddard, A. (2003). Accountability verstehen: A study of accounting in state religious councils in Malaysia. Discussion Paper in Accounting and Finance. International Islamic University Malaysia

Rahman, F., K., K., Tareq, M., A., Yunanda, R. A. \& Mahdzir, A. (2017). Maqasid Al-Shariah-based performance measurement for Halal industry. Humanomics, 357-370.

Rahman, Z., A., (2014). Fiqh Kewangan Islam: Halal dan Haram dalam Sistem Jual Beli Islam. PTS Islamika Sdn Bhd.

Ramli, N., M. \& Ali, N., S (2017). Governance Reporting in Islamic Philanthropic Organizations, Contemporary Issues on Zakat, Waqf and Islamic Philanthropy. Academy of Contemporary Islamic Studies (ACIS) UiTM, 367 - 382.

Ramli., N., M., Muhammad I., H., K., and Muhamed, N., A. (2016). The Financial Management Perspective of Islamic Social Enterprise. In Critical Readings in Islamic Social Finance. 2, YTI Lecture Series, 229-254. USIM Press. Retrieved from http://apps.isiknowledge.com/full_record .do?product=UAandsearch_mode=GeneralSearchandqid=3andSID=4B8M87JhCkefbkLEhb@and page $=1$ anddoc $=24$ and colname $=$ MEDLINE.

Robert, G. E., \&Saltzman, D. (2001). Achieving sustainability through integrated. Social Innovation Review Summer, 56-61.

Rossouw, R., (2011). Integrating Sustainability Reporting. Presentation delivered at the Women in Finance Conference, South Africa. Retrieved from http//www.slideshare.net.

Ruzita M. A., Selamah A. Y., Mohamed A. H., Mustafa O. M., \& Oziev. G. (2013). The Integrated Development Index (I-Dex): A New Comprehensive Approach to Measuring Human Development. Paper presented at an International Conference on Islamic Economics and Finance Growth, Equity and Stability: An Islamic Perspective. Istanbul, Turkey.

Saunah, Z. et al. (2013). Annual reports of non-profit organizations (NPOs): An Analysis. Journal of Modern Accounting and Auditing, 9(2), 183-192.

Sproat, P. (2005), The social impact of counter terrorist finance policies in the UK. Crime, Law and Social Change, 44, 441-464.

Trussel, J. M., \& Parsons, L. M (2008). Financial reporting factors affecting donations to charitable organisations. Advance in Accounting, 23, 263-285.

United Nations Development Programmes-UNDP (2012). Strategy for Working with the Private Sector.

WIFE. (2015, Nov 3). Speeches. Retrieved from https://wief.org/speech/gala-dinner-special-address-hr-h-sultan-nazrin-muizzuddin-shah-ibni-almarhum-sultan-azlan-muhibbuddin-shah-almaghfur-lah-sultan-perak-darul-ridzuan/.

Yaacob, H., S. Petra, A. Sumardi \& H. S. Nahar (2012). Awqaf accounting and reporting for accountability: A case study of awqaf. The 19th International Research Conference. Monash University, November 19 -21 2012, Melbourne, Australia. 